\title{
MANAGING ECONOMIC EFFECTIVENESS OF MARKETING IN TRANSNATIONAL COMPANIES
}

\author{
Oksana BULKOT'1, Lidia PASHCHUK² \\ Taras Shevchenko National University of Kyiv, Ukraine
}

\begin{abstract}
The purpose. The purpose of the study is a generalization of international experience with regard to marketing efficiency control and development of qualitative and quantitative methods to be implemented in the estimation of marketing activity of TNCs. Methodology. The survey is based on research, conducted for 60 companies in the spring of 2015 (32\% of which were Ukrainian and 68\% - offices and affiliates of international companies), namely Bayer, Coca-Cola, Pepsi Co, Mondelez, Mars, Mintel, Cargill, and many others. The practical results of monitoring the effectiveness of annual plans of named companies done by authors through implementing original author' methodology based on presenting key performance indicators (KPI). Results. The theoretical approaches to the estimation of marketing efficiency are analysed. The conditions, under which the organization is working by analysing external environment and internal company's potential, are determined. It is substantiated by the authors that direct development of marketing plans should be based on marketing objectives, developed as a result of the situational analysis. It is proved that monitoring the effectiveness of annual plans may be done by implementing key performance indicators that enable to develop quantitative evaluation system of the organization's strategy, based on control of its goals. The results of the research allowed authors to distinguish two major groups of effectiveness indicators for TNCs, which are financial and marketing indicators. In this standpoint, financial indicators are divided into costs', productivity and profitability indicators and to the marketing effectiveness indicators belong market indexes, competitiveness indexes, and client's indicators. Practical implications. The proposed methodology can be implemented for the qualitative and quantitative estimation of marketing effectiveness not only in TNCs but in small and medium business companies as well. Value/originality. The authors proved that marketing effectiveness indicators provide a weighty addition to traditional indicators of financial stability estimation of TNCs.
\end{abstract}

Key words: management of company's effectiveness, economical effectiveness, transnational company, marketing management.

JEL Classification: M310, M11, M19

\section{Introduction}

Marketing plays an important role in international companies as means of achieving commercial success in the process of attracting consumers; however, the efficiency of marketing efforts is often being ignored. Considering crisis conditions, the problem of economic advisability and efficiency evaluation of marketing are becoming of particular importance in the economies of different countries and transnational companies' activities since marketing function can be perceived at the corporate level as consuming and as non-profitable. It is extremely important to develop a unified approach towards the evaluation of marketing efficiency and control in the companies, working in multiple countries. Therefore, development and generalization of current approaches toward the marketing efficiency control are extremely relevant.
Formulation of objectives. Search for theoretical approaches and development of practical recommendations regarding implementation of marketing control in international companies on all marketing stages. The purpose of the study. The purpose of the study is the generalization of international experience with regard to marketing efficiency control.

\section{Literature review}

G. Armstrong, P. Kotler, W. Kennet, J.-E. Mason all relate to famous scientists in the marketing sphere that raised in their works the issue of marketing complex and evaluation of marketing efficiency. In Ukraine, works of the following scientists are devoted to the issue of marketing efficiency: L. Balabanova, A. Balabanyts, A. Dlihach, Y. Mytrokhina, Y. Romat, R. Kanayan,

Corresponding author:

${ }^{1}$ Department of International Economics and Marketing, Taras Shevchenko National University of Kyiv.

E-mail: o.bulkot@gmail.com

${ }^{2}$ Department of International Economics and Marketing, Taras Shevchenko National University of Kyiv.

E-mail: lidia_paschuk@yahoo.com 
O. Kanishchenko, M. Kotliarenko, A. Starostina, B. Ivanchenko, and others. The problem of control over marketing efficiency has not received a proper attention; therefore, it needs further research and recommendations development for Ukrainian market.

Unsolved parts of the problem. Nowadays, most of the international studies on the mentioned topic can be used in developed and developing countries. However, the issue of unified systematic approach towards the efficiency control in different countries in different areas still remains open. Moreover, considering political instability of Ukraine's economy, internal factors need to be objectively taken into account since they can influence the selection of consumer behaviour management's methods.

\section{Research key points}

Marketing is one of the key functions in any company that ensures satisfaction of economic needs of market relations' parties (Kotler, Armstrong, 1997), namely consumers' needs in terms of profitability (Haldane, 2009). First of all, marketing is management function. P. Kotler suggests considering management based on APIC approach where A stands for analysis, $\mathrm{P}$ - for planning, I - for implementation, and $\mathrm{C}$ - for control (Kotler, 1988).

The systematic and logical approach is meant here. First of all, we need to determine conditions, under which the organization is working by analysing the external environment and internal company's potential. The results of the conducted marketing audit should be summarized in SWOT-analysis. The next stage is the direct development of marketing plans based on marketing objectives, developed as a result of the situational analysis. Developed plans fall under the implementation during the next stage, evaluation of implementation efficiency and analysis of management mistakes are the final stage. Herewith marketing within the organization should be cyclic and control results should be taken into account for further marketing planning, as illustrated in Fig. 1

Taken into account the fact that marketing can be characterized by cyclical nature, it is worth mentioning that control plays an important role in marketing since it provides a basis for further decision-making. Reaching results is only possible if problematic spheres of organization's activities are detected timely. Therefore, regular and systematic control is extremely necessary. Moreover, a majority of transnational companies, namely, Bayer, Coca-Cola, Pepsi Co, Mondelez, Mars, Mintel, Cargill, and many others, have a unified approach that verification of developed plans implementation and achieved results needs to be made once a year. The results of research, conducted for 60 companies in the spring of 2015 (32\% of which were Ukrainian and 68\% - offices and affiliates of international companies) demonstrated that in the majority of companies (85\%), a control over marketing performance is applied, however, with no single approach. Companies' or affiliates' managers in cooperation with marketing specialists are responsible for control.

Also, it is worth mentioning that $80 \%$ of Ukrainian companies need assistance in conducting control because they do not have their own understanding of how to conduct the process of control over marketing activities.

However, 96\% of foreign companies use globally accepted approaches and consider them successful and those that contribute to further success for the company and brands. Summarizing a positive experience of domestic and foreign companies, the major types of

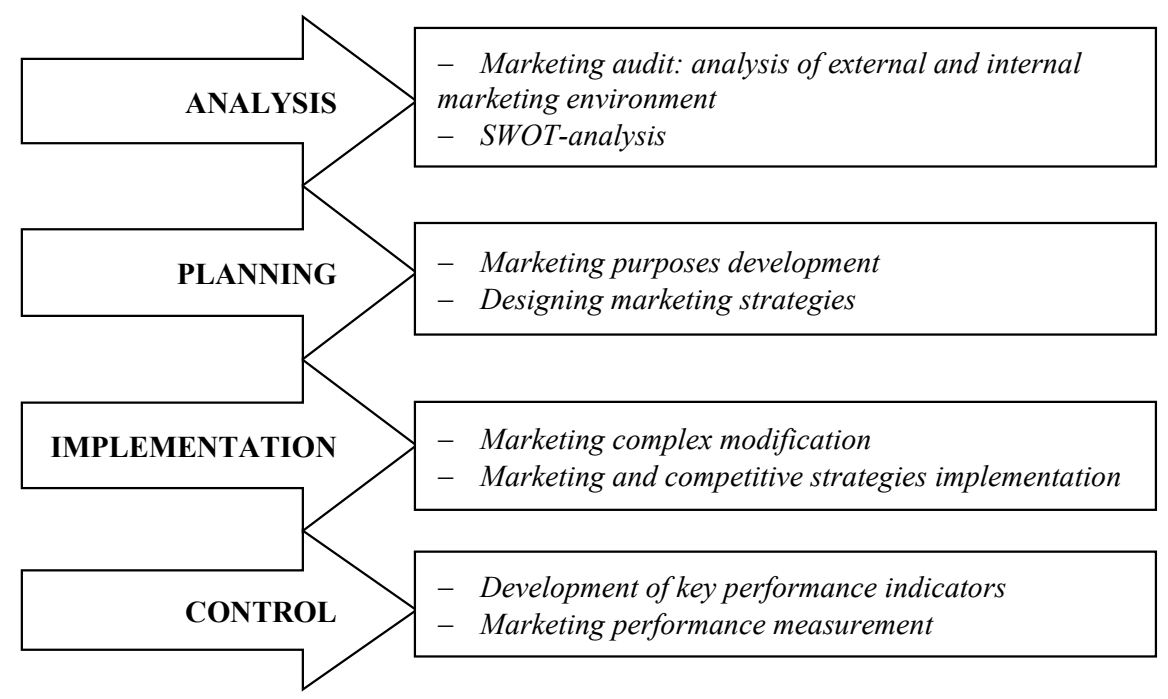

Fig. 1. APIC - marketing management activities basis

Source: designed by the authors based on (Kotler, 1988) 

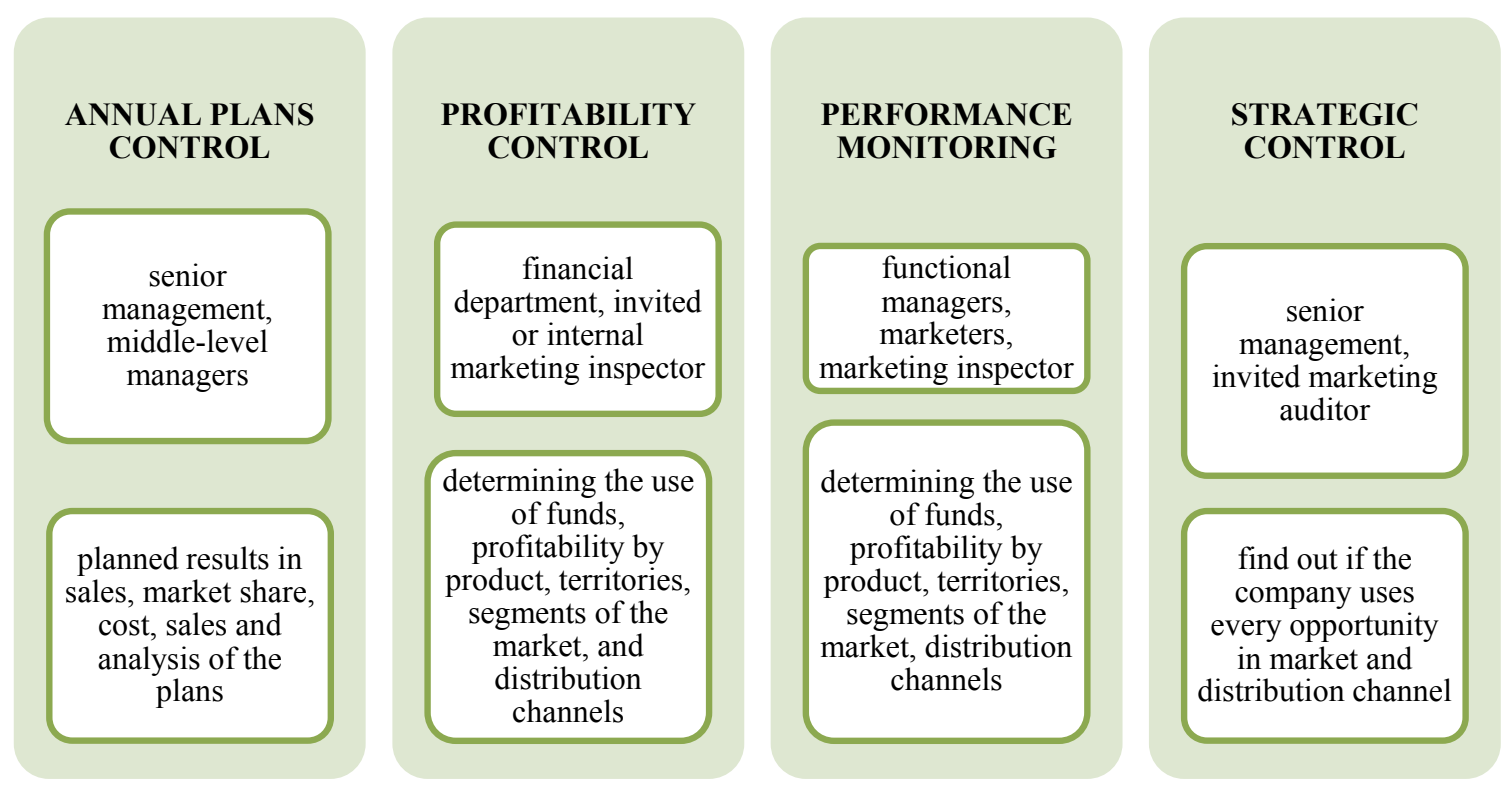

Fig. 2. Types and purposes of marketing control

Source: designed by the authors based on (Kotler, 1988)

marketing control that can be used by organizations can be distinguished. These types are: controlling of annual plans, sales control, control of marketing objectives, monitoring performance, and strategic control. At Fig. 2 below, the objectives of each type of control, as well as responsibilities and objectives of control based on P. Kotler work, and the results of research conducted by the author, are summarized.

Monitoring the effectiveness of annual plans may be done by implementing key performance indicators (KPI). Such indicators enable to develop quantitative evaluation system of the organization's strategy, based on control of its goals. Key performance indicators can be quantitative and qualitative. Quantitative will have a numerical value and quality will mainly relate to brand or company attitude and perception of consumers and key stakeholders. The majority of companies $(78 \%)$ that have been surveyed, agreed with the expediency of development of key performance indicators based on marketing objectives, as shown in Table 1.

The next type of marketing control that should be considered is marketing control of profitability. Determination of income that derived from marketing activities is rather controversial and not all marketers are able to define it. Determination of the effectiveness of marketing is one of the most difficult elements of marketing activity. According to the Business Dictionary, effectiveness means "the degree to which objectives are achieved and the extent to which targeted problems are solved." In contrast to efficiency, effectiveness is determined without reference to costs. The costs arising from the implementation and development of marketing activities are fairly easy to calculate but measurement of the implementation effect seems to be impossible sometimes. This is due to the fact that marketing activity

Table 1

Development KPIs of Marketing Activities

\begin{tabular}{|c|c|c|c|c|}
\hline MARKETING GOAL & KPI & CONTROL METHOD & SUCCESS & FAILURE \\
\hline $\begin{array}{l}\text { To gain the } 60 \% \text { level of brand awareness } \\
\text { ( } 45 \% \text { in } 2014 \text { ) sportswear for mountain } \\
\text { climbing classes for men and women } 20-45 \\
\text { years old that live in Kiev during } 2015 \text {. }\end{array}$ & $\begin{array}{l}60 \% \text { brand awareness } \\
\text { among men and women } \\
20-45 \text { years living in Kiev } \\
\text { and involved climbing }\end{array}$ & Poll representative sample & $60 \pm 2 \%$ & Less than $60 \%$ \\
\hline $\begin{array}{l}\text { Increase the number of corporate customers } \\
\text { at more than } 15 \text { cleaning companies in } \\
\text { September } 2015\end{array}$ & 15 new customers & Internal reporting & 15 Companies & Less than 15 \\
\hline $\begin{array}{l}\text { Increase sales of face cream at Ukrainian } \\
\text { market at } 5 \% \text { (from X tons in 2014) by the } \\
\text { end of } 2015\end{array}$ & Sales volume in tonnes & Internal reporting & $\mathrm{X}$ tons $+5 \%$ & $\begin{array}{l}\text { Less than } \mathrm{X} \text { tons } \\
+5 \%\end{array}$ \\
\hline $\begin{array}{l}\text { Launch new cookies and ensure sales of } \\
10,000 \text { packages for } 2015 \text { in Ukraine. }\end{array}$ & Sales volume in packages & Internal reporting & $\begin{array}{l}10,000 \text { packages } \\
\text { and more }\end{array}$ & $\begin{array}{c}\text { Less than } \\
10000 \text { packages }\end{array}$ \\
\hline
\end{tabular}

Source: designed by the authors based on own research 
involves two groups of achieving goals: market return, financial payback.

Based on the research results, the authors decided to consider two major groups of effectiveness indicators for TNCs, which are financial and marketing indicators.

Financial indicators encompass tree main groups:

(1) costs' indicators (cost-price of goods, marketing costs, current costs);

(2) productivity indicators (stocks goods turnover, sales per worker, and bills receivables);

(3) profitability indicators (sales profitability, assets profitability, and investments profitability).

Marketing effectiveness indicators provide a weighty addition to traditional indicators of financial stability estimation of TNCs. They allow marketing managers to understand and monitor the effectiveness of the market and to manage it with the help of marketing strategy (Kaplan, Norton, 1992).

The marketing effectiveness indicators are divided into three subgroups:

(1) market indexes (market expansion factors, market share, market demand potential);

(2) competitiveness indexes (quality of goods and services, relative price, and value);

(3) client's indicators (client's satisfaction, saving client's maintenance and loyalty) (Chen, Hess, 1999).

As we can see, indicators of marketing effectiveness can be internal, i.e. refer to the internal environment of the company, and external, i.e. refer to the external environment of the company. In turn, the internal and external indicators are divided into current ever-changing indicators - that require continuous monitoring that is often carried out with the help of marketing information system, and final - indicators that are used as marketing objectives of the company and are estimated, as a rule, on the basis of quarter, year. That is why we can affirm that the main aim of implementation of marketing indicators is the current estimation of its efficiency. And as a lot of its indexes anticipate the financial result of TNC's activity, that group of indicators is of the high importance for achieving that result.

We can define four main methods of estimation of marketing efficiency:

1. Sociological methods of evaluating the effectiveness of marketing tools aimed at the use of applied sociology - a program of sociological research and, according to it, the conduct of the study. Moreover, evaluation of the effectiveness of marketing communications is focused on the use of the tools of applied sociology.

2. Scoring methods for evaluating the effectiveness of marketing "isolate" its effectiveness for each action to comply with eligibility criteria of the list of structures and processes of marketing concepts with setting a score for each criterion.
3. Qualitative methods involve the use of marketing audit, during which performed a comprehensive analysis of the external environment of the organization, as well as all threats and opportunities. It is possible to distinguish two areas of marketing control: resultsoriented marketing control, and marketing audits, i.e. analysis of the qualitative aspects of the TNC.

4. Quantitative methods of estimation of the marketing effectiveness require comparing the costs of marketing with the resulting gross margin and advertising costs to sales. Actually, they characterize the final financial results of the TNC.

Because of the tight interrelation between the effectiveness of marketing and the final financial result of TNC's activity, the quantitative methods of estimation of the marketing effectiveness now became very popular and applied. That is why further we will focus our attention on analysing different types of quantitative methods for the estimation of the marketing effectiveness in TNCs.

Thereof, the main seven groups of quantitative methods in marketing research could be proposed for applied use:

1. Multivariate methods (primarily factor and cluster analysis). They are used to support marketing decisions, which are based on many interrelated variables. For example, the determination of the volume of sales of a new product depending on the technical level, price, advertising costs, and other elements of the marketing mix.

2. Regression and correlation models. Used to establish the relationship between groups of variables, describing marketing activities.

3. Simulation methods. They are used when the variables affecting a marketing situation (for example, describing the competition) are not amenable to analytical solution.

4. Methods of statistical decision theory. Used to describe the stochastic response of consumers to changes in the market situation.

5. Deterministic models of operations research (primarily linear and nonlinear programming). These methods are used when there are many interrelated variables, and it is necessary to find the optimal solution, for example, a variant of delivery of the product to the consumer, ensuring the maximum profit, one of the possible channels of goods allocation.

6. Hybrid methods, combining deterministic and probabilistic (stochastic) characteristics. They are used primarily to study distribution problems.

7. Models of network planning.

Of course, the quantitative methods are not exhausted only by named above seven groups.

The marketing effectiveness of TNC impacts also macro and micro environmental factors, as well as direct marketing mix ("4P"). In applied use, we can demonstrate those linkages through the interrelation of the sales revenue and sales volume of TNC. 
To determine the marketing effectiveness in TNC, it is necessary while developing a marketing plan to define the criteria, accordingly to which there will be the measurement of the implementation of the marketing plan (monitoring results of marketing activities).

Defining expenses related to the marketing (estimation of costs for marketing budget) and the marketing effectiveness indicator itself is determined by comparing the effect achieved as a result of marketing activities (which is often but not necessarily expressed in the form of profits or revenue) to the costs caused by this effect.

To determine the marketing effectiveness, it is also necessary to determine the effect (result) of this activity.

The economic effect of marketing can be expressed in figures: an increase in sales (in value and volume terms), an increase in income from sales of products, increase market share of a particular company.

Using the quantitative method of estimation of marketing effectiveness results by constructing a mathematical model, we can assess the cost-effectiveness of marketing activities. In general, the formula for calculating the efficiency is as follows:

$$
E=B / C
$$

where E - Efficiency; B - Benefit; C - Cost.

Through such an equation, we can express the effect of marketing in TNC:

$$
M E=\Delta P(m) / C(m)
$$

where ME - Marketing Effectiveness;

$\Delta \mathrm{P}(\mathrm{m})$ - an increase in profit due to the marketing event;

$C(m)$ - expenditures for the marketing event.

It worth to be said that under the effect of marketing in TNC, there can be understood its goal, expressed quantitatively. But in practice, the set of marketing purposes range of different activities have different goals. So we think it would be better to choose one main indicator, and through it to calculate the efficiency of each event.

For example, the effectiveness of marketing costs could be estimated using the rates of return on invested capital (sometimes - working capital), which is calculated by the following formula:

$$
P I C=(N R / S) \times(s / C I)
$$

where PIC - Profit on Invested Capital;

NR - Net Return;

$S$ - Sales;

CI - Invested Capital.

In this aspect, the methodology of complex estimation of TNC's competitive range by estimation of marketing measures effectiveness seems for us very interesting.

Analysis of managing the marketing effectiveness in TNC is advisable to be based on the calculation of the dynamics indicators that characterize profitability of the commercial activity of TNC and its competitiveness:

- the proportion of income from commercial activities of the TNC;

- the volume of shipped products;

- the volume of demand for the company's products (market size);

- costs of marketing service;

- the coefficient of competitiveness of TNC (Sudnik, 2004).

Profitability of commercial activities of TNC is advisable to carry out by determining the coefficient of competitiveness that is represented as aggregated amount of the following groups of coefficients: product competitiveness, price competitiveness, promotion competitiveness, distribution/sales competitiveness (it should be mentioned that each group includes subgroups of coefficients to be calculated).

To calculate the final coefficient of competitiveness of TNC, it also needs to be taken into account the overall financial ratios, calculated on the basis of the analysis of the balance and financial statements of TNC. The ratio of mentioned coefficient allows defining the type/position of TNC in the market that is divided into market leaders, market contenders, market followers, market nichers, bankrupts (Sudnik, 2004).

Nevertheless, the implementation of quantitative methods for the estimation of marketing effectiveness is limited for the following reasons:

- the complexity of the object of study, the nonlinearity of the marketing process, the presence of threshold effects, such as a minimum level of sales promotion, time lags (e.g., consumer response to advertising is often not carried out immediately);

- the effect of the interaction of marketing variables that for the most part are interdependent, such as price, range, quality, production volume;

- the complexity of the measurement of marketing problems; difficult to measure consumer reaction to certain stimuli, such as advertising, so there are often used indirect methods of assessment;

- instability of marketing linkages, due to changes in tastes, habits, assessments et al., the incompatibility of personnel involved in the marketing and use of quantitative methods in its assessment.

First priority is given to informal methods, second to mathematical modelling. The above it is largely due to the fact that the marketing deal with human behaviour, and not to technical phenomena.

\section{Conclusion}

The implementation of marketing plans of the TNC in practice may have many unforeseen circumstances. That is why one of the tasks of the marketing department is the ongoing assessment of the economic efficiency 
of marketing in the TNC. The timely and qualitative assessment of the results of marketing activities undertaken by the TNC influences its position in the market and future development.

Estimation of economic efficiency of marketing is an essential part of the control of marketing. Marketing control is an assessment of progress in the implementation of marketing strategies and plans and the implementation of corrective actions to achieve their goals.

Estimation of economic efficiency of marketing activities is very important, especially at the stage of decision-making on specific activities. This raises the question about the procedures of determining the effectiveness of marketing activities at the planning stage.

Implementation of marketing activities will be certainly accompanied by certain financial investments. It is from the standpoint of the effectiveness of these investments are often assessed the effectiveness of marketing. The TNC shall estimate the profitability of transactions (in relation to certain categories of consumers, distribution channels etc.). This information will identify the need for expansion or contraction of markets, assortment, marketing activities.

The research showed that the problem of determining the economic efficiency of marketing activity has two objectives:

1. The efficiency of marketing activities under development or decision; selection of the optimal variant.

2. Determination of the ultimate effectiveness of marketing activities after the end of a period of time based on actual results.

Determining the cost-effectiveness of marketing activities, it is also necessary to identify the factors that influence the rate of efficiency of marketing activity, their interdependence, if it is the nature of their impact on the efficiency index, identify the reserves increase efficiency.

Evaluating the effectiveness of marketing activities is very challenging, and not always given the opportunity to quantify the effect produced by marketing activities. There are a lot of others, not described above approaches for the estimation of the marketing efficiency and their applicability in TNCs that could give new impulses for researching these issues.

\section{References:}

Haldane, G. (2009). Professional Diploma in Marketing. Study Text. Project Management in Marketing. London : BPP Learning Media, Aldine Place, 218 p.

Kotler, P., Armstrong, G., Saunders, J. and Wong, V. (2005), Principles of Marketing: Fourth European Edition, Prentice Hall, Harlow, 954 p.

Kotler, P. and Armstrong, G. (1997) Marketing An Introduction. Fourth Edition. New Jersey. Prentice Hall International, $585 \mathrm{p}$.

Kotler, P., (1988) Marketing Management: Analysis Planning and Control, Prentice-Hall, 776 p.

Kaplan, R., and Norton, D. (1992).The Balanced Scorecard — Measures That Drive Performance, Harvard Business Review (January-February 1992), 71-79.

Chen, Y., Hess, J., Wilcox, R., and Zhang, Z. J. (1999). Accounting Profits Versus Marketing Profits: A Relevant Metric for Category Management. Marketing Science, 18, no. 3, 208-229.

Sudnik, V. (2004) Estimation of marketing efficiency of the enterprise. Guide for economist, №8, Marketing (in rus.)

\section{Оксана БУЛКОТ, Лидия ПАЩУК}

\section{УПРАВЛЕНИЕ ЭКОНОМИЧЕСКОЙ ЭФФЕКТИВНОСТЬЮ МАРКЕТИНГА В ТРАНСНАЦИО- НАЛЬНЫХ КОМПАНИЯХ}

Аннотация. Целью работы является обобщение международного опыта оценивания эффективности маркетингового контроля, а также разработка качественных и количественных моделей системы контроля маркетинга в деятельности транснациональных корпораций. Методология. Исследование является результатом авторского изучения и анализа 60 компаний, произведенного весной 2015 (32\% из которых украинские, и 68\% - филии и дочерние предприятия иностранных транснациональных корпораций), а именно Bayer, Coca-Cola, Pepsi Co, Mondelez, Mars, Mintel, Cargill и прочие. Практические результаты анализа эффективности годовых отчетов упомянутых выше компаний, обобщены путем использования авторской методики, которая базируется на применении ключевых результативных индикаторов к анализу эффективности деятельности ТНК. Результаты. Анализируются теоретические подходы к оценке эффективности маркетинга. Определяются условия, в которых организация работает, анализируя внешнюю среду и потенциал внутренней компании. Авторами обосновано, что прямая разработка маркетинговых планов должна основываться на маркетинговых целях, разработанных в результате ситуационного анализа. Доказано, что мониторинг эффективности годовых планов может быть осуществлен путем внедрения ключевых показателей эффективности, которые позволят разработать количественную систему оценки 
стратегии организации, основанную на контроле ее целей. Результаты исследования позволили авторам выделить две основные группы показателей эффективности для ТНК - финансовые, которые делятся на показатели затрат, производительности и рентабельности и маркетинговые, к которым относятся рыночные индексы, индексы конкурентоспособности и клиентские показатели. Практическое значение. Предложенная авторами методика может быть практически применена для качественного и количественного оценивания эффективности маркетинговой деятельности не только в крупных ТНК, но и на предприятиях малого и среднего бизнеса. Значение/оригинальность. Авторское исследование подтвердило гипотезу, что использование специфических индикативных показателей для оценивания эффективность маркетинговой деятельности обеспечивает существенный непосредственный эффект, который влияет на оценку и конечную финансовую результативность деятельности ТНК. 